\title{
Risk factors of falling among hospitalized patients with neurological disease - post-fall analysis
}

\section{Czynniki zwiększające ryzyko upadku wśród hospitalizowanych pacjentów $z$ chorobami neurologicznymi - analiza poupadkowa}

\author{
Michaela Miertová, Ivana Bóriková, Martina Tomagová, Jaroslav Madleňák, Marián Grendár, Anna Barnau \\ Department of Nursing, Jessenius Faculty of Medicine in Martin, Comenius University in Bratislava, Slovak Republic \\ Head of the Department: Katarína Žiaková Prof., MSC, PhD.
}

Key words: neurological disease, fall risk factor, patient, hospitalization, post-fall analysis.

Słowa kluczowe: choroba neurologiczna, czynnik ryzyka upadku, pacjent, hospitalizacja, analiza poupadkowa.

\begin{abstract}
Introduction: Post-fall analysis of fall risk factors is an effective intervention in minimizing the fall risk in inpatients. Aim of the research: To identify significant fall risk factors in patients with neurological disease, who fell during hospitalization. Material and methods: Forty adult inpatients were included in a retrospective quantitative cross-sectional study, who fell in the neurological department in the period 01/2014-01/2020. The research protocol contains selected fall risk factors, the Morse Fall Scale (MFS), and the Barthel ADL Index. The Random Forest method was used to identify significant fall risk factors. ROC with AUC was used to assess the predictive value of fall risk factors.

Results: The mean age of the sample was $70.50 \pm 15.20$ years. The most common fall risk factors in the sample included the following: gait, balance and mobility disorders, polymorbidity $\geq 5$ medical diagnoses, and polypharmacotherapy $\geq 5$ drug classes. The mean MFS score was high $(75.8 \pm 26.6)$, and the after-fall MFS score increased $(97.8 \pm 22.5)$. The median score of the Barthel ADL Index indicated partial dependency in groups with and without fall in their history. The Random Forest identified significant falls risk predictors between the groups with and without fall in their history: fear of falling, number of drugs taken in $24 \mathrm{~h}$, level of independence, and fall risk during admission. The predictive value of fall risk factors expressed by ROC curve was AUC $=0.842$.

Conclusions: The identification of significant factors in the after-fall analysis should lead to a revision of work procedures aimed at their prevention.
\end{abstract}

\section{Streszczenie}

Wprowadzenie: Analiza poupadkowa czynników ryzyka upadku stanowi skuteczny środek zmniejszania ryzyka wystąpienia zdarzeń tego rodzaju u hospitalizowanych pacjentów.

Cel pracy: Określenie istotnych czynników ryzyka upadku u pacjentów z chorobami neurologicznymi, u których wystąpił upadek w okresie hospitalizacji.

Materiał i metody: Do retrospektywnego, przekrojowego badania ilościowego włączono 40 dorosłych pacjentów hospitalizowanych na oddziale neurologicznym od stycznia 2014 r. do stycznia 2020 r., u których wystapił upadek. W protokole badania uwzględniono wybrane czynniki ryzyka upadku, skalę upadków Morse’a (MFS) oraz skalę podstawowych czynności życia codziennego (ADL) Barthel. Do identyfikacji istotnych czynników ryzyka upadku wykorzystano metodę lasu losowego (random forest). Wartość predykcyjną poszczególnych czynników ryzyka upadku oszacowano z zastosowaniem krzywej ROC z polem powierzchni pod krzywą (AUC).

Wyniki: Średni wiek w próbie badanej wynosił 70,5 $\pm 15,2$ roku. Ustalono, że do najczęstszych czynników ryzyka upadku należały: zaburzenia chodu, równowagi i ogólnie mobilności, wielochorobowość ( $\geq 5$ rozpoznań) oraz polifarmakoterapia ( $\geq 5$ klas leków). Średni wynik pacjentów w skali MFS był wysoki $(75,8 \pm 26,6)$, a po upadku odnotowano jego dalszy wzrost $(97,8 \pm 22,5)$. Stwierdzono częściową zależność ryzyka od mediany wyniku w skali ADL Barthel zarówno w grupie, w której wystąpił upadek, jak i w grupie bez upadku w wywiadzie. Metodą random forest zidentyfikowano istotne predyktory ryzyka upadków w grupach z upadkiem i bez upadku w wywiadzie: lęk przed upadkiem, liczba leków przyjmowanych w ciagu doby, stopień samodzielności oraz ryzyko upadku przy przyjęciu do szpitala. Wartość predykcyjna czynników ryzyka upadku na podstawie krzywej ROC wyniosła $\mathrm{AUC}=0,842$.

Wnioski: Określenie istotnych czynników ryzyka upadku na podstawie analizy poupadkowej powinno prowadzić do rewizji procedur szpitalnych pod kątem zapobiegania takim zdarzeniom. 


\section{Introduction}

Concerning patients' safety, falling during hospitalization is the most common unwanted or extraordinary event $[1,2]$ as well as an indicator of the quality of healthcare provided in several countries in the world [3]. The review of scientific literature revealed that the definition of the notion "fall" is not consistent, a generally valid definition of a fall not having been adopted yet. According to Morse, a fall is an unforeseen, unplanned, and unexpected event, unintentional, suddenly calculated, the patient's fall to the ground, floor or another area of lower altitude, or onto another person, or another object [4].

Falls are common in patients with neurological diseases and are a primary cause of injuries. Fall incidence is $2-4$ times higher in patients with neurological diseases than in healthy subjects of similar age, and $46 \%$ of neurological patients reveal one or more falls per year [5]. According to Zhou et al., compared with healthy subjects, neurological patients had an increased risk of falling (49\%) within 20 months [6].

Post-fall analysis of fall risk factors is an important and effective intervention in preventing and minimizing the risk of falling in adult hospitalized patients. It focuses on the factors leading to falls, identifies deficiencies in operating procedures and patient assessment, promotes staff awareness of fall prevention responsibilities, and lowers the probability of overlooking key risk factors for falls [7, 8]. Through this analysis, healthcare professionals are able obtain valuable information on the issue of falls in a specific group of patients in a particular type of medical treatment unit. A thorough analysis of the causes of a fall plays a crucial role in the prevention of repeated falls in the same patient as well as in the development of safety procedures for healthcare staff. A retrospective post-fall analysis contributes to the re-assessment of risk factors in the patient, or to the identification of other factors that were not captured in the initial assessment. In the fall prevention process, nurses play an important role in assessing and managing the fall risk as well as improving the safety of hospitalized patient's falls $[7,9]$. The importance of post-fall assessment and the following implementation of targeted and planned risk reduction interventions is supported by evidence, because a fall documented in the past is the best indicator for a future fall [10].

In neurological unit, inpatients fall twice as much as in other units due to their current medical condition, mainly due to the presence of mobility, gait and balance disorders, and due to the effects of prescribed pharmacotherapy [11]. In this group of patients, the risk of falling and the fall itself can also be understood as a non-specific clinical symptom of several neurological diseases, while the mechanism of the fall is characteristic of each of them [12]. The fall is the result of several intrinsic and extrinsic risk factors, whereby different patients may have different combinations of these risk factors [11]. Thus, the fall is mainly associated with increased morbidity (including injuries of varying severity, functional limitations), dependence on the help of others, longer hospital stays, and the development of ptophobia. Falls in hospitalized patients have a negative impact on their physical (e.g. injury, pain, mobility impairment) and mental conditions (e.g. negative experience, distress, being insecure, ptophobia) [13]. Falls and their consequences in hospitalized patients are a serious public health problem and have a negative economic impact on society $[9,14]$.

\section{Aim of the research}

The aims of the study were, first, to identify significant risk factors for falls in the sample of inpatients with neurological disease who fell during hospitalization; second, to determine if there is a significant difference in the incidence of fall risk factors in the 2 groups of patients, without and with a fall in their personal history; and, third, to recognize significant fall risk factors in the sample by means of the depth of a graph.

\section{Material and methods}

The sample consisted of 40 adult hospitalized patients who met predefined classification criteria: age $\geq 18$ years; neurological disease; and a fall in a neurological department during hospitalization. The participants who did not meet all 3 of the criteria were excluded.

Study design: retrospective quantitative cross-sectional study.

Empirical data collection was carried out through a retrospective content analysis of the medical records of the patients who fell during hospitalization in the neurological department of the university hospital in the period 01/2014-01/2020. The research protocol had 2 parts: First, a list of risk factors for falls - falls occurrence and frequency in the patient was determined; second, screening for risk of falling according to the Morse Fall Scale (MFS) as well as the individual's independence in daily activities according to the Barthel Index of Activities of Daily Living (ADL). The list of risk factors for falls was as follows: a fall in personal history; gender; age; length of hospitalization; neurological medical diagnosis on admission; other neurological disease in personal history; polymorbidity $\geq 5$ medical diagnoses; polypharmacotherapy $\geq 5$ drug classes; number of drugs taken in $24 \mathrm{~h}$ (oral and parenteral); diagnosed impaired gait, balance, and mobility; use of a walking aid; mental state, continence, vision, hearing, sleep; and fear of falling. We considered a fall in personal history as a key risk factor. Based on this fact, we divided the file into 2 sub-files - without a fall and with a fall in a personal history (Tables 1 and 2). The fall risk has been identified through the MFS as- 
Table 1. Risk factors for falls in the sample of patients $(N=40)$

\begin{tabular}{|c|c|c|c|c|}
\hline Risk factor & $\begin{array}{c}\text { Total } \\
N=40(100 \%)\end{array}$ & $\begin{array}{c}\text { Without a fall in PH } \\
N=29(72.5 \%)\end{array}$ & $\begin{array}{l}\text { With a fall in PH } \\
N=11(27.5 \%)\end{array}$ & $P$-value \\
\hline \multicolumn{5}{|l|}{ Gender: } \\
\hline Male & $24(60.0)$ & $17(59.0)$ & $7(64.0)$ & \multirow[t]{2}{*}{$>0.9^{\mathrm{a}}$} \\
\hline Female & $16(40.0)$ & $12(41.0)$ & $4(36.0)$ & \\
\hline \multicolumn{5}{|l|}{ Age: } \\
\hline Me (Q1, Q3) & $75(64.0 ; 82.0)$ & 75 (62.0; 82.0) & $71(64.79)$ & $0.7^{c}$ \\
\hline \multicolumn{5}{|c|}{ Length of hospitalization: } \\
\hline Me $(\mathrm{Q} 1, \mathrm{Q} 3)$ & $11.5(7.0 ; 16.2)$ & $11(6.0 ; 17.0)$ & $14(8.5 ; 15.5)$ & $0.6^{c}$ \\
\hline \multicolumn{5}{|c|}{ Polymorbidity $\geq 5$ medical diagnoses: } \\
\hline No & $2(5.0)$ & $2(6.9)$ & $0(0)$ & \multirow[t]{2}{*}{$>0.9^{b}$} \\
\hline Yes & $38(95.0)$ & $27(93.0)$ & $11(100)$ & \\
\hline \multicolumn{5}{|c|}{ Other neurological disease in a personal history: } \\
\hline No & $15(38.0)$ & $8(28.0)$ & $7(64.0)$ & \multirow[t]{2}{*}{$0.065^{a}$} \\
\hline Yes & $25(62.0)$ & $21(72.0)$ & $4(36.0)$ & \\
\hline \multicolumn{5}{|c|}{ Polypharmacotherapy $\geq 5$ drug classes: } \\
\hline No & $6(15.0)$ & $4(14.0)$ & $2(18.0)$ & \multirow[t]{2}{*}{$>0.9^{b}$} \\
\hline Yes & $34(85.0)$ & $25(86.0)$ & $9(82)$ & \\
\hline \multicolumn{5}{|c|}{ Use of antipsychotics: } \\
\hline No & $31(78.0)$ & $25(86.0)$ & $6(55.0)$ & \multirow[t]{2}{*}{$0.083^{a}$} \\
\hline Yes & $9(22.0)$ & $4(14.0)$ & $5(45.0)$ & \\
\hline \multicolumn{5}{|c|}{ Number of drugs/24 h (oral, parenteral): } \\
\hline Me (Q1, Q3) & $12(8.8 ; 17.0)$ & $12(8.0 ; 16.0)$ & $10.0(9.5 ; 18.5)$ & $0.7^{c}$ \\
\hline \multicolumn{5}{|c|}{ Gait, balance, and mobility disorder: } \\
\hline No & $0(0)$ & $0(0)$ & $0(0)$ & \multirow[t]{2}{*}{-} \\
\hline Yes & $40(100)$ & $29(100)$ & $11(100)$ & \\
\hline \multicolumn{5}{|l|}{ Walking aid: } \\
\hline No & $23(57.0)$ & $18(62.0)$ & $5(45.0)$ & \multirow[t]{2}{*}{$0.5^{a}$} \\
\hline Yes & $17(42.0)$ & $11(38.0)$ & $6(55.0)$ & \\
\hline \multicolumn{5}{|c|}{ Mental disorder: } \\
\hline No & $16(40.0)$ & $13(45.0)$ & $3(27.0)$ & \multirow{2}{*}{$0.5^{b}$} \\
\hline Yes & $24(60.0)$ & $16(55.0)$ & $8(73.0)$ & \\
\hline \multicolumn{5}{|c|}{ Continence disorder: } \\
\hline No & $26(65.0)$ & $19(66.0)$ & $7(64.0)$ & \multirow[t]{2}{*}{$>0.9^{\mathrm{a}}$} \\
\hline Yes & $14(35.0)$ & $10(34.0)$ & $4(36.0)$ & \\
\hline \multicolumn{5}{|l|}{ Vision disorder: } \\
\hline No & $16(40.0)$ & $10(34.0)$ & $6(55.0)$ & \multirow[t]{2}{*}{$0.3^{a}$} \\
\hline Yes & $24(60.0)$ & $19(66.0)$ & $5(45.0)$ & \\
\hline \multicolumn{5}{|c|}{ Aid for visual impairment: } \\
\hline No & $29(72.0)$ & $18(62.0)$ & $11(100)$ & \multirow[t]{2}{*}{$0.019^{b}$} \\
\hline Yes & $11(28.0)$ & $11(38.0)$ & $0(0)$ & \\
\hline
\end{tabular}


Table 1. Cont.

\begin{tabular}{|c|c|c|c|c|}
\hline Risk factor & $\begin{array}{c}\text { Total } \\
N=40(100 \%)\end{array}$ & $\begin{array}{c}\text { Without a fall in PH } \\
N=29(72.5 \%)\end{array}$ & $\begin{array}{l}\text { With a fall in PH } \\
N=11(27.5 \%)\end{array}$ & $P$-value \\
\hline \multicolumn{5}{|c|}{ Hearing impairment: } \\
\hline No & $35(88.0)$ & $24(83.0)$ & $11(100)$ & \multirow[t]{2}{*}{$0.3^{b}$} \\
\hline Yes & $5(12.0)$ & $5(17.0)$ & $0(0)$ & \\
\hline \multicolumn{5}{|c|}{ Sleep disorder: } \\
\hline No & $20(50.0)$ & $13(45.0)$ & $7(64.0)$ & \multirow{2}{*}{$0.5^{a}$} \\
\hline Yes & $20(50.0)$ & $16(55.0)$ & $4(36.0)$ & \\
\hline \multicolumn{5}{|c|}{ Fear of falling: } \\
\hline No & $19(48.0)$ & $19(66.0)$ & $0(0)$ & \multirow{2}{*}{$<0.001^{b}$} \\
\hline Yes & $21(52.0)$ & $10(34.0)$ & $11(100)$ & \\
\hline
\end{tabular}

$\mathrm{PH}$ - personal history, $\mathrm{N}$ - absolute abundance, \% - relative abundance, ${ }^{a}$ Fisher's exact test, ${ }^{b} \chi^{2}$ test of independence, ${ }^{c}$ Wilcoxon test.

Table 2. Continuous variables as risk factors for falls in the sample of patients $(n=40)$

\begin{tabular}{|c|c|c|c|c|}
\hline Risk factor & $\begin{array}{c}\text { Total } \\
N=40(100 \%)\end{array}$ & $\begin{array}{c}\text { Without a fall in PH } \\
N=29(72.5 \%)\end{array}$ & $\begin{array}{l}\text { With a fall in PH } \\
N=11(27.5 \%)\end{array}$ & $P$-value \\
\hline \multicolumn{5}{|c|}{ MFS on admission to neurological unit: } \\
\hline Me $(\mathrm{Q} 1, \mathrm{Q} 3)$ & $80(50 ; 95)$ & $70(45 ; 95)$ & $95(78 ; 102)$ & $0.043^{c}$ \\
\hline \multicolumn{5}{|l|}{ MFS after a fall: } \\
\hline Me (Q1, Q3) & $100(75 ; 116)$ & $95(75 ; 115)$ & $110(98 ; 122)$ & $0.2^{c}$ \\
\hline \multicolumn{5}{|c|}{ Barthel ADL Index on admission to neurological unit: } \\
\hline $\mathrm{Me}(\mathrm{Q} 1, \mathrm{Q} 3)$ & $58(45 ; 81)$ & $60(45 ; 90)$ & $50(42 ; 78)$ & $0.5^{c}$ \\
\hline
\end{tabular}

$\mathrm{PH}$ - personal history, $\mathrm{N}$ - absolute abundance, \% - relative abundance, ' Wilcoxon test.

sessment tool, which is recommended for use when admitting a patient to a hospital, continuously over the course of hospitalization when the health condition changes, after a fall in a medical treatment unit, before patient discharge [4]. In the original study, the sensitivity of MFS was $78 \%$, specificity $83 \%$, and inter-rater reliability $r=0.96$ [15]. MFS is also a suitable assessment tool for patients with neurological disease $[1,16,17]$. The tool assesses 6 risk factors for a fall: 1. history of falling; immediately or within 3 months; 2. secondary diagnosis (> 1 diagnosis); 3. ambulatory aid; 4. intravenous line/therapy/heparin lock; 5. gait disorders/transferring; and 6. mental status. The total fall risk score is $0-125$; risk of falling is low $\leq 20$, medium/moderate $25-40$, and high $\geq 45$ (cut-off score 45 defines patients with high and low risk of falling and is a starting point for the implementation of specific preventive interventions) [4]. The diagnostic reliability of the MFS tool was assessed by calculating the predictive validity that includes the Receiver Operating Characteristic (ROC) curve and the area under the ROC curve (AUC), which graphically visualizes the outputs of the diagnostic test. The AUC ranges from 0 to 1 (or
0-100\%) and serves as the standard to determine the diagnostic effectiveness of the test. An AUC value greater than 0.75 is considered discriminatory [18].

The level of individual independence in activities of daily living was monitored through the Barthel ADL Index, which is filled out in the neurology department when the patient is admitted to hospital. The assessment tool was originally developed for patients with neuromuscular and musculoskeletal diseases, with an indication of long-term rehabilitation care. The variance of reliability ranges between 0.87 and 0.93 , and good predictive validity is reported [19]. In patients with neurological disease, it is recommended that staff assess their independence level on admission to hospital, but also during hospitalization [17].

Data collection was carried out by 1 researcher and 1 trained nurse.

\section{Ethical aspects of the study}

The project researchers received approval for its implementation from the Ethics Commission of the University Hospital in Martin. Protocol for the re- 
search project conforms to the provisions of the Declaration of Helsinki of 1989. Before the beginning of the study, we asked the head of the Department of Neurology and the head of the Nursing Department of the University Hospital in Martin for permission to access the archives of patients' medical records and to collect data.

\section{Statistical analysis and evaluation of empirical data}

Empirical data were coded and subsequently recorded into a Microsoft Excel database and evaluated in the SPSS statistical program, version 18.0, PASW Statistics 18 and R Core Team [20] version 3.5.2 using the MASS library [21] and the Random Forest SRC library (Random Forest for Survival, Regression, and Classification, RF-SRC) [22]. Descriptive statistics describe fall risk factors as calculating absolute $(\mathrm{N})$ and relative (\%) abundance. For continuous variables, the median (Me, $x$ ), lower quartile (Q1), and upper quartile (Q3) are given when determining the height of the risk of falling and the level of independency. Fisher's exact test, the $\chi^{2}$ test of independence, and the Wilcoxon test were used to identify fall risk factors. Due to the fact that the data file contains more parameters than observations, it is not possible to use the statistical method of logistic regression to model the relationship between fall risk prediction and fall risk factors. Machine learning (ML) methods do not have such a limitation, so we used one of the ML methods - the Random Forest method [23, 24] - to identify significant fall risk factors. The Random Forest algorithm split the fall risk factors according to their significance and at the same time identified predictors that do not carry any information when determining the prediction of fall risk in a patient with neurological disease during hospitalization. We used the depth of a graph in ML methods to measure the predictive ability (discrimination) of the predictor; the smaller its numerical value (closer to the number 0 ), the more substantial the predictor. Using the depth of the graph, the predictors are arranged from most significant to least significant. The Random Forest algorithm determines also the threshold analogous to the $p$-value threshold of 0.05 . To assess the predictive value of the fall risk factors that Random Forest identified as significant, a Receiver Operating Characteristic (ROC) curve was used, evaluating the area under the curve (AUC). Empirical data were tested at a significance level of $5 \%(p<0.05)$.

\section{Results}

The sample consisted of 40 adult hospitalized patients with a fall during hospitalization, of which 24 $(60.0 \%)$ were men and $16(40.0 \%)$ were women. The mean age of the sample was $70.50 \pm 15.20$ years (min. 23, max. 93), the mean length of hospitalization was
$12.0 \pm 6.5$ days (min. 2, max. 32). Present neurological diagnoses were diagnosed in these patients on their admission to the neurological unit: cerebrovascular diseases (I60-I69) $(N=27 ; 67.5 \%)$, other dorsopathies (M50-M54) $(N=3 ; 7.5 \%)$, epilepsy and recurrent seizures (G40) $(N=1 ; 2.5 \%)$, vascular syndromes of the brain in a cerebrovascular disease $(\mathrm{G} 46)(N=1 ; 2.5 \%)$, other disorders of the brain (G93) $(N=2 ; 5.0 \%)$, malignant neoplasm of the brain (C71) $(N=1 ; 2.5 \%)$, biomechanical lesions, not elsewhere classified (M99) $(N=1$; $2.5 \%$ ), demyelinating diseases of the central nervous system (G35-G37) ( $N=1 ; 2.5 \%)$, polyneuropathies and other disorders of the peripheral nervous system (G60-G64) $(N=1 ; 2.5 \%)$, and Parkinson's disease (G20) $(N=1 ; 2.5 \%)$ according to ICD-10. The frequency of each fall risk factor in the sample, for the groups with and without a fall in their personal history, is presented in Table 1. Our data based on the MFS tool show that those respondents who had a fall in their personal history more often had another neurological disease in their personal history, used antipsychotics, had a fear of falling, and less often declared the use of an aid for the visually impaired (Table 1).

The median MFS score in the sample, for groups with and without a fall in their personal history, on admission to the neurological unit was high; after the fall, the MFS score increased. The median score of the Barthel ADL Index indicated partial dependency in the sample of patients, both in groups with and without a fall in their personal history (Table 2).

The Random Forest method was used to rank fall risk factors according to their importance and identified the following factors as significant predictors of fall risk: fear of falling, number of drugs taken in $24 \mathrm{~h}$, level of independence, and risk of falling on the patient's admission. Using the depth of the graph in ML methods, the essential predictors are arranged from most significant to least significant (Table 3).

Using the ROC curve constructed from the Random Forest method, we found a very good predictive value of fall risk factors (listed in Table 3) for predicting falls during hospitalization, as indicated by the area under the ROC curve, AUC $=0.842$ (84.2\%) (Figure 1).

\section{Discussion}

Our present study aimed, first, to identify significant risk factors for falls in the sample of inpatients with neurological disease who fell during their hospitalization; second, to compare the incidence of falls in the patients without and with a fall in their personal history, because some studies consider a fall in the personal history to be the most significant predictor of further falls [14]. Our results show that ptophobia was present in all patients with a positive history of falls. Thus, ptophobia was a significant fall risk factor, increasing the risk of a fall during a hospital stay (Ta- 
Table 3. Significant risk factors for falls in the sample of patients $(N=40)$

\begin{tabular}{|lc|}
\hline Risk factor & Depth of the graph \\
Fear of falling & 1.82 \\
Number of drugs/24 h & 2.88 \\
$\begin{array}{l}\text { Independence level according } \\
\text { to the Barthel ADL Index on } \\
\text { admission }\end{array}$ & 3.06 \\
$\begin{array}{l}\text { Fall risk level according to the } \\
\text { MFS on admission }\end{array}$ & 3.08 \\
\hline
\end{tabular}

ble 1). According to Enderlin et al., if a patient falls, he/ she will usually be afraid of another fall, which may result, for example, in the patient's conscious reduction of his/her mobility [25]. In this connection, it is necessary to say that fear (ptophobia) also develops in patients who have never experienced a fall, because the fear of falling increases with age due to fear of being injured and hospitalized [26]. Patients suffering from ptophobia are at higher risk of falling, regardless of their neurological disease [27]. In clinical practice, it is recommended that experts assess the personal history of falls (as a fall risk factor) in all neurological patients on their admission, to minimize the risk of falling during a hospital stay $[9,28]$. Another significant risk fall factor, which in our study increased the risk of falls during hospitalization in the group of patients with a personal history of falls, was the use of antipsychotics (Table 1). As well as antipsychotics, several other drugs have been associated with an increased risk of falling, such as antidepressants, anticonvulsants, antiparkinsonians, analgesics, and opiates [7]. Consequently, antipsychotic medication may increase the risk of falls in patients with neurological disease as a consequence of orthostatic hypotension, gait abnormalities, sedation, dizziness, and uncoordinated movements (bad side effects) [29, 30]. We assume that the use of these groups of drugs may be related to the treatment of the patient's current medical condition or other associated diseases in their personal history. Other neurological disease in the patient's personal history was another significant risk fall factor increasing the risk of falling in the group of patients with a personal history of falls during their hospital stay (Table 1). As the number of secondary diagnosis increases, including other neurological disease in the personal history, so does the fall risk during hospitalization [31, 32]. We assume that a higher number of secondary diagnoses (including polymorbidity $\geq 5$ medical diagnoses) is closely related to the mean age of patients in our sample (70.5 years). According to Nugraha et al., the morbidity increases with increasing age of the patient, and polymorbidity increases the fall risk linearly, especially in the elderly population, e.g. if the patient has 2 or more diseases,

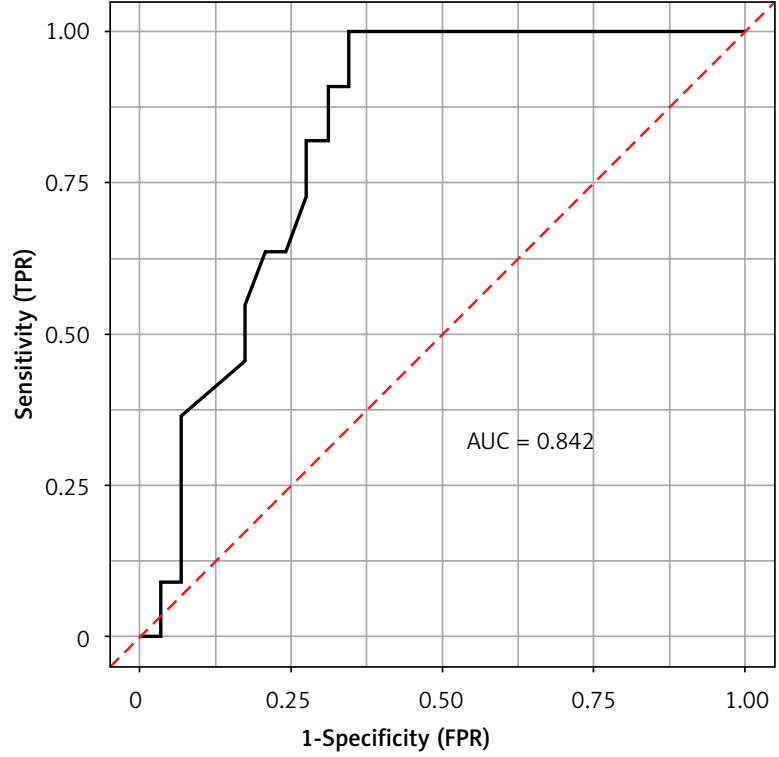

Figure 1. ROC curve for assessing the predictive value of fall risk factors in the sample of patients $(n=40)$

the fall risk doubles [33]. Using the MFS assessment tool on admission, we also assume that polymorbidity as well as a positive history of falls are the cause of increased risk of falling in our present study. According to Habiba et al., hospitalized patients with neurological disease are at high risk of falling [9]. This high-risk group includes, for instance, patients suffering from cerebrovascular diseases who fall repeatedly during their hospital stay [34, 35] as well as patients with Parkinson's disease [36], brain cancer [37], epilepsy [38], neuropathies [39], and multiple sclerosis [40]. In our study, an aid for visual impairment has also been confirmed as a significant risk factor for falling in patients without a personal history of falls (Table 1). We assume that, with regard to the mean age as well as the present neurological diagnosis of the study participants, our results are related to physiological changes connected to aging in the visual organ. Zhang et al., maintain that impaired visual acuity increases the fall risk in elderly [41]. In some neurological diseases, the clinical symptomatology is associated with visual disturbances or sensory changes, e.g. in multiple sclerosis [12] and stroke [31], and its management involves using a compensatory aid for visual impairment.

Concerning the third aim of our study, we identified significant fall risk factors in the sample by means of the depth of a graph. Our study results showed the following significant fall risk factors: fear of falling, number of drugs taken in $24 \mathrm{~h}$, level of independence according to the Barthel ADL Index on admission, and risk of falling according to the MFS on the patient's admission (Table 3, Figure 1). Due to the mean age of our sample (70.5 years) as well as level of independence according to the Barthel ADL Index (both are risk factors predicting patient falls), it is im- 
portant to monitor fear of falling. According to published research papers, fear of falling affects mobility and the patient's level of functional independency (according to ADL), and it increases the risk of further (repeated) falls during a hospital stay, which also increases the risk of institutionalization [42]. In relation to this, special attention should be paid to patients after a stroke [43] or multiple sclerosis [39], because they express their fear of falling during hospitalization. In our study, the independence level according to the Barthel ADL Index was confirmed as a significant predictor of falls (Table 3). This fact is probably related to patients' medical diagnoses (current and in their personal history), their symptomatology, and the mean age of the sample. According to research studies, the fall risk increases with a number of risk factors, such as the patient's functional dependency, especially in personal hygiene and transfer [44]. It also influences motor, cognitive, and perceptual abilities [45], and relates to gait, balance, and movement disorders. In this context, it is important to emphasize that in neurology, gait balance and movement disorders are the most common symptoms of the disease as well as the cause of repeated falls [46]. The above-mentioned symptoms occurred in all patients in our sample. Other significant risk factors include the number of drugs taken in $24 \mathrm{~h}$. In our cohort, patients received, orally and parenterally, an average (median) of 12 medications (Table 1). Concerning the higher number of drugs, we assume it is related to the treatment of the patient's current health condition (according to their present neurological diagnosis) as well as to polymorbidity and the mean age of the sample. In relation to this, it is necessary to say that in neurology, the severity of the health condition is associated with an increased number of drugs from different drug classes. According to Ambrose et al., geriatric polymorbid patients as well as patients of younger age groups are exposed to fall risk due to the spectrum of neurological diseases and the current health condition of the patient [47]. The last significant fall risk factor was the MFS fall risk score (Table 3). In our sample, patients already belonged to the high-risk group on admission due to the risk factors detected by the MFS screening tool (Table 2). The MFS tool is a suitable screening tool in this particular group of patients [1, 2, 4, 48]. The benefit of the MFS screening tool is that it simultaneously detects several significant risk factors for falls $[4,15]$. In our research study, the diagnostic test had AUC 0.842 (84.2\%), i.e. high discriminative effectiveness (accuracy) of the test (Figure 1).

The research study was carried out in one healthcare facility. The level of functional independence according to the Barthel ADL Index was not assessed after the fall. Furthermore, fear of falling and mental health after the fall were not examined. Another limitation of the study is its small sample size. Fur- thermore, our sample comprised a high number of patients with cerebrovascular disorders (after stroke), whereas some of the other neurological diagnoses were rather rare (e.g. demyelinating diseases of the central nervous system, polyneuropathy, Parkinson's disease). Thus, our results may primarily apply to patients with stroke and are less relevant to another group of patients with neurological diseases. Generalizing the study results is possible with a larger sample size. Therefore, our findings may be the starting point for further research conducted in a larger number of patients with neurological disease.

\section{Conclusions}

The results of the after-fall analysis showed the presence of specific fall risk factors that are typical in patients with neurological disease. Even the identification of a fall in a personal history, as important for objectifying the fall risk, should lead to the assessment of other risk factors, including functional status of the patient using measuring tools. The identification of factors that proved to be significant in the postfall analysis should lead to a revision of work procedures aimed at their prevention. The study results can also be a useful starting point for further research regarding the prevention of falls, as well as the establishment of a national standard to prevent falls during hospitalization.

\section{Acknowledgments}

The authors would like to thank head of the Department of Neurology and the head of the Nursing Department of the University Hospital in Martin for permission to access the archives of patients' medical records and to collect data.

The study was created under the auspices of the project KEGA 048UK-4/2016 Fall Risk Assessment - for education and practice by The Ministry of Education, Science, Research, and Sport of the Slovak Republic.

\section{Conflict of interest}

The authors declare no conflict of interest.

\section{References}

1. Yoo SH, Kim SR, Shin YS. A prediction model of falls for patients with neurological disorder in acute care hospital. J Neurol Sci 2015; 356: 113-117.

2. Sung YH, Cho MS, Kwon IG, Jung MR, Kim K, Won S. Evaluation of falls by inpatients in acute care hospital in Korea using the Morse Fall Scale. Int J Nurs Pract 2014; 20: 510-517.

3. Kim KS, Kim JA, Choi YK, Kim YJ, Park MH, Kim HY, Song MS. Comparative study of the validity of fall risk assessment scales in Korean hospitals. Asian Nurs Res 2011; 5: 28-37. 
4. Morse J. Preventing patient falls. Establishing a Fall Intervention Program. Springer Publishing Company. LLC, New York 2009.

5. Ehrhardt A, Hostettler P, Widmer L, Reuter K, Petersen JA, Straumann D, File L. Fall-related functional impairments in patients with neurological gait disorder. Sci Rep 2020; 10: 21120 .

6. Zhou Y, Rehman R, Hansen C, Maetzler W, Din SD, Rochester L, Hortobágyi T, Lamonth CJC. Classification of neurological patients to identify fallers based on spatial-temporal gait characteristics measured by a wearable device. Sensors 2020; 20: 4098.

7. Kafantogia K, Katsafourou P, Tassiou A, Vassou N. Falls among hospitalized patients. J Frailty Sarcopenia Falls 2017; 2: 53-57.

8. Gu YY, Balcaen K, Ni Y, Ampe J, Goffin J. Review on prevention of falls in hospital settings. Chin Nurs Res 2016; 3: 7-10.

9. Habiba AIAE, Gomaa S, Gomaa S. Nurse's assessment of falling risk and barriers of patients' safety measures among patients with neurological disorders, at Tanta University Hospital, 2018. EJHC 2018; 9: 348-360.

10. AHQR. Preventing falls in hospitals: A toolkit for improving quality of care. Agency for Health Care Research and Quality, January 2013. AHQR publication, No. 13-0015-EF.

11. https://www.ahrq.gov/sites/default/files/publications/files/fallpxtoolkit.pdf.

12. Comino-Sanz IM, Sánchez-Pablo C, Albornos-Muñoz L, Alejandre IB, De Vicuña Marin MJ, Uribesalgo Pagalday L, Gamarra Santa Coloma E. Falls prevention strategies for patients over 65 years in a neurology ward: a best practice implementation project. JBI Database of Syst Rev Implement Rep 2018; 16: 1582-1589.

13. Camicioli R. Falls in aging and neurological disease. In: Clinical neurology of aging. Albert ML, Knoefel JE (eds.). Oxford University Press, New York 2011; 297-313.

14. Sung YH, Cho MS, Kwon IG, Jung MR, Kim K, Won S. Evaluation of falls by inpatients in acute care hospital in Korea using the Morse Fall Scale. Int J Nurs Pract 2014; 20: 510-517.

15. Zampogna A, Mileti I, Palermo E, Celletti C, Paoloni M, Manoni A, Mazzetta I, Dalla Costa G, Pérez-López C, Camerota F, Leonaci L, Cebestany J, Irrera F, Suppa A. Fifteen years of wireless sensors for balance assessment in neurological disorders. Sensors 2020; 20: 3247.

16. Morse JM, Morse RM, Tylko SJ. Development of a scale to identify the fall-prone patient. Can J Aging 1989; 8: 366-377.

17. Najafpour Z, Godarzi Z, Arab M, Yaseri M. Risk factors for falls in hospital in-patients: a prospective nested case control study. Int J Health Policy Manag 2019; 8: 300-306.

18. Bougiouklis D, Psychogyios NV, Plessas S, Konstas A, Louverdis I. Risk factors and functional outcomes of surgical treatment of fall-related hip fractures in patients with Parkinson's disease. JNSK 2020; 10: 70-76.

19. Dušek L, Pavlík T, Jarkovský J, Koptíková J. Analýza dát v neurologii - XXVIII. Hodnocení diagnostických testů křivky ROC. Cesk Slov Neurol N 2011; 74/107: 493-499.

20. Mahoney FI, Barthel DW. Functional evaluation: the Barthel Index. Md State Med J 1965; 14: 61-65.

21. R Core Team. A language and environment for statistical computing. R Foundation for Statistical Computing, Vienna, Austria 2018; https://www.R-project.org/.

22. Venables WN, Ripley BD. Modern Applied Statistics with S. Springer. New York 2002.
23. Ishwaran $\mathrm{H}$, Kogalur UB. Fast Unified Random Forests for Survival, Regression, and Classification (RF-SRC), R package version 2.9.1; https://cran.r-project.org/web/packages/randomForestSRC/randomForestSRC.pdf.

24. Breiman L. Random forests. Mach Learn 2001; 45: 5-32.

25. Enderlin C, Rooker J, Ball S, Hippensteel D, Alderman J, Fisher SJ, McLeskey N, Jordan K. Summary of factors contributing to falls in older adults and nursing implications. Geriatr Nurs 2015; 36: 397-406.

26. Růžičková V, Zeleníková R. Strach z pádu u senior ve zdravotnických a sociálních zařízeních. Ošetrovatel'stvo: teória, výskum, vzdelávanie 2017; 7: 6-11.

27. Jahn K, Freiberger E, Eskofier BM, Bollheimer C, Klucken J. Balance and mobility in geriatric patients. Assessment and treatment of neurological aspects. Z Gerontol Geriat 2019; 52: 316-323

28. Swift CG, Iliffe S. Assessment and prevention of falls in older people - concise guidance. Clin Med 2014; 14: 297-302.

29. Stroup TS, Gray N. Management of common adverse effects of antipsychotic medications. World Psychiatry 2018; 17: 341-356.

30. Fraser LA, Liu K, Naylor KL, Hwang YJ, Dixon SN, Shariff SZ, Garg AX. Falls and fractures with atypical antipsychotic medication use: a population-based cohort study. JAMA Int Med 2015; 175: 450-452.

31. Mun Tan K, Pin Tan M. Stroke and falls - clash of the two titans in geriatrics. Geriatrics 2016; 1: 31.

32. Jarošová D, Majkusová K, Zeleníková R, Kozáková R, Líčeník R, Stolička M. Prevence pádů a zranění spůsobených pády u starších dospělých. Adaptovaný klinický postup [Prevention of falls and falls injuries in the elderly (2005), Supplement (2011)]; https://dokumenty.osu.cz/lf/uom/ uom-publikace/kdp-pady-plna-verze.pdf.

33. Nugraha S, Hapsari I, Sabarinah Pengpid S, Peltzer K. Multimorbidity increases the risk of falling among Indonesian elderly living in community dwelling and elderly home: a cross sectional study. Indian J Public Health Res Dev 2019; 10: 2011-2016.

34. Wei WE, De Silva DA, Meng Chang H, Yao J, Matchar DB, Young SHY, Ju See S, Hsiang Lim G, Hwany Wong T, Venketesubramanian N. Post-stroke patients with moderate function have the greatest risk of falls: a National Cohort Study. BMC Geriatr 2019; 19: 373.

35. Kotlęga D, Meller A, Gołąb-Janowska M, Pawlukowska W, Nowac P. The early outcome of thrombolytic treatment in ischaemic stroke patients: a retrospective analysis. Med Stud 2019; 35: 16-22.

36. Canning CG, Paul SS, Nieuwboer A. Prevention of falls in Parkinson's disease: a review of fall risk factors and the role of physical interventions. Neurodegener Dis Manag 2014; 4: 203-221.

37. Stone CA, Lawlor PG, Savva GM, Bennett K, Kenny RA. Prospective study of falls and risk factors for falls in adult with advanced cancer. J Clin Oncol 2012; 30: 2128-2133.

38. Leppik IE, Yang H, Williams B, Zhou S, Fain R, Patten A, Bibbiani F, Laurenza A. Analysis of falls in patients with epilepsy enrolled in the perampanel phase III randomized double-blind studies. Epilepsia 2017; 58: 51-59.

39. Homann B, Plaschg A, Grundner M, Haubenhofer A, Griedl T, Ivanic G, Hofer E, Fazekas F, Homann CN. The impact of neurological disorders on the risk for falls in the community dwelling elderly: a case-controlled study. BMJ Open 2013; 3: e003367. 
40. Cameron MH, Nilsagard Y. Balance, gait, and falls in multiple sclerosis. Handb Clin Neurol 2018; 159: 237-250.

41. Zhang XY, Shuai J, Li LP. Vision and relevant risk factor interventions for preventing fall among older people: a network meta-analysis. Sci Rep 2015; 5: 10559.

42. Beh SY, Mccullagh R, O’Neill E, Healy L. Older inpatients' experience and insights into fear of falling: a feasibility study. Physiother Pract Res 2019; 40: 1-8.

43. Jalayondeja C, Sullivan PE, Pichaiyongwongdee S. Six-month prospective study of fall risk factors identification in patients' post-stroke. Geriatr Gerontol Int 2014; 14: 778-785.

44. Tanaka B, Sakuma M, Ohtani M, Toshiro J, Matsumura T, Morimoto T. Incidence and risk factors of hospital falls on long-term care wards in Japan. J Eval Clin Pract 2012; 18: 572-577.

45. Mlinac EM, Feng MC. Assessment of activities of daily living, self-care, and independence. Arch Clin Neuropsychol 2016; 31: 506-516.

46. Nonnekes J, Goselink R, Růžička E, Nutt J. Neurological disorders of gait, balance and posture: a sign-based approach. Nat Rev Neurol 2018; 14: 183-189.

47. Ambrose AF, Cruz L, Paul G. Falls and fracture: a systematic approach to screening and prevention. Maturitas 2015; 82: 85-93.

48. Materese M, Ivziku D, Bartolozzi F, Piredda M, De Marinis MG. Systematic review of fall risk screening tools for older patients in acute hospitals. JAN 2015; 71: 1198-1209.

\section{Address for correspondence:}

Michaela Miertová MSN, PhD, RN

Jessenius Faculty of Medicine

Comenius University in Bratislava

Martin, Slovak Republic

E-mail: michaela.miertova@uniba.sk 